\title{
RUANG SOSIAL SEBAGAI PRODUK NEGOSIASI SPASIAL DI KAMPUNG KAUMAN YOGYAKARTA
}

\author{
Septiawan Bagus Panglipur ${ }^{1}$, Sita Yuliastuti Amijaya ${ }^{2}$ \\ 1,2. Magister Arsitektur, Fakultas Arsitektur dan Desain, Universitas Kristen Duta Wacana \\ Jl. dr. Wahidin Sudirohusodo No. 5-25, Yogyakarta \\ Email: sbsakamoto@gmail.com
}

\begin{abstract}
Abstrak
Kampung Kauman Yogyakarta merupakan salah satu daerah yang memiliki keunikan pada sejarah, pola tatanan warga dan permukiman. Warga Kauman merupakan keturunan abdi dalem Kraton Yogyakarta. Kauman merupakan tempat dimulainya ajaran Islam Muhammadiyah oleh K.H. A. Dahlan. Ruang-ruang dan penggunanya merupakan hal yang menarik di Kauman. Gang-gang sempit tidak hanya digunakan untuk lalu-lintas warga, namun juga dimanfaatkan sebagai ruang berkegiatan. Hal tersebut menciptakan ruang baru. Ruang baru juga tercipta dari perluasan sementara teritori hunian warga yang sudah disepakati. Penelitian ini bertujuan untuk menganalisis terbentuknya ruang-ruang sosial baru oleh kegiatan warga dengan menggunakan metode deskriptif kualitatif berdasarkan aktivitas warga Kampung Kauman tersebut. Hasilnya, pola perilaku manusia dalam berkegiatan pada lingkungannya mampu menciptakan ruang baru (sementara dan permanen). Temuan ruang sosial bergerak di Kauman adalah ruang sosial yang diciptakan oleh pedagang keliling, mereka membuka ruang baru di sekitar area penjualan. Temuan akuisisi temporal terdapat pada jemuran yang diletakkan pada ruas jalan kampung yang merupakan milik bersama, sehingga membuat pemilik jemuran memiliki ruang personal baru dan menutup ruang sosial yang sudah ada sebelumnya. Halaman Masjid Agung yang biasanya kosong digunakan untuk kegiatan pencak silat, kegiatan tersebut menyebabkan para pedagang asongan datang untuk berjualan di sana.
\end{abstract}

Kata kunci: Kampung Kauman, ruang sosial, ruang sementara, ruang personal.

\begin{abstract}
Title: Configuration of Social Space as a Result of Space Negotiation in Kampung Kauman Yogyakarta

Kauman is one of the unique special area in Yogyakarta famous for the special formation of the settlement patterns and the history as well related to the inhabitant. Kauman residents are descendants of the courtiers of Kraton Yogyakarta. Kauman is known as the birth place of K.H. A. Dahlan, the founder of Muhammadiyah Islamic teachings. The use of spaces as the result of communities behaviour could be seen as an interesting phenomenon. Narrow paths ways are not only used for access but also used as spaces for activities. It creates kind of new spaces. Some temporary extension of residential areas is often found and accepted as an agreement among residents. The aim of this study is to analyze the formation of the new social spaces by community activities. The qualitative descriptive methods will be used to explain the activities of Kauman village residents. Human activities behavior creates patterns in the in the environment as new spaces both temporary and permanent. The research finding of a moving social space in Kauman is a social space created by traveling vendors as they open new spaces around the sales area. The other finding is temporary acquisition of the clothesline which is placed along the alley that become a shared property, this make the clothesline owner have a new personal space occupying the social space that already exists. The court yard of the Great Mosque whenever empty is used for pencak silat activities, this activity also attracts the hawkers to come to sell there.
\end{abstract}

Keywords: Kampung Kauman, social space, temporary space, personal space. 


\section{Pendahuluan}

Sebuah kota selalu memiliki kisah di balik terbentuknya kota tersebut, begitu juga Kota Yogyakarta. Sebuah kerajaan yang dahulu sempat berjaya di Nusantara pernah berdiri di Yogyakarta, dimulai dari Kerajaan Mataram Islam, yang kemudian terbagi menjadi dua kerajaan yaitu Kasunanan Surakarta dan Kasultanan Ngayogyakarta.

Pada masa Kerajaan Mataram, sang raja menggunakan konsep yang disebut Catur Gatra. Elemen dari konsep ini terbagi menjadi 4, yaitu: Keraton (istana), alun-alun, Masjid Gedhe (Masjid Agung) dan pasar. Yogyakarta pun menerapkan konsep yang sama. Alun-alun berada di sebelah utara dan selatan keraton, di sebelah utara alunalun ada Pasar Beringharjo dan di sebelah timur terdapat Masjid Agung dan Kampung Kauman.

Alun-alun menjadi tempat berjumpanya sultan (raja) dengan rakyat. Pasar sebagai pusat pertumbuhan ekonomi dan Masjid Agung menjadi tempat ibadah, bersama dengan sebuah kampung di dekatnya, yaitu Kampung Kauman. Kampung ini merupakan tempat tinggal para petinggi agama Islam yang bertugas di Masjid Agung, yang sering disebut Kaum.

Pada masa itu, Sultan Hamengku Buwono I mengumpulkan para ulama yang tinggal di sekitar masjid. Selain para ulama, juga hadir para ahli agama atau ketib/penghulu yang menetap di masjid tersebut. Selanjutnya, masingmasing mendirikan langgar yang berfungsi sebagai pesantren di tempat tersebut. Selain itu, sultan juga telah menyiapkan 40 abdi dalem yang diperintahkan untuk memakmurkan masjid tersebut. Selanjutnya orangorang yang tinggal di sekitar masjid tersebut menegakkan ajaran Islam yang dikenal sebagai Qaaimuddin, yang kalau diucapkan dalam lidah jawa menjadi pakauman dan selanjutnya lebih dikenal dengan nama Kauman.

Pada awal abad ke-20, tepatnya pada tahun 1912, lahir gerakan pembaharuan Islam Muhammadiyah di Kauman yang dimotori oleh K.H. Ahmad Dahlan. Beliau adalah salah seorang khatib (tokoh yang sering memberikan ceramah agama, sekaligus tokoh formal pengurus masjid) pada saat itu. Gerakan ini menginginkan pemurnian kembali ajaran Islam kepada $A l$ Qur'an dan Sunnah, dari Islam tradisionalis yang sinkretis (tercampur dengan budaya Hindu, Budha dan Animisme) menjadi Islam yang reformis, yaitu Islam yang bersih dari paham tradisional yang seringkali tak sejalan dengan nilai keislaman (Darban, 2000 dan Sativa, 2012).

Gerakan tersebut terbukti bisa dikatakan berhasil. Namun, meskipun ajaran Islam reformis tersebut sudah berhasil disebarkan, para warga masih tetap saja mengaplikasikan nilai-nilai Jawa terutama pada sopan-santun atau unggah-ungguh dalam tingkah dan laku mereka. Bangunan rumah di Kauman saat ini sudah mulai beralih ke bangunan Jawa yang modern, namun layout kampungnya tidak banyak mengalami perubahan.

Kauman memiliki gang-gang kecil yang memaksa kendaraan beroda empat atau lebih tidak bisa masuk. Bahkan, kendaraan roda dua pun harus dimatikan dan dituntun jika ingin memasuki kawasan kampung ini. Gang-gang kecil tersebut juga seolaholah merekatkan persaudaraan dan kekerabatan antar warga kampung. Semakin dekatnya jarak (jalan) antar rumah membuat mereka tidak segan untuk mengunjungi tetangganya. Dalam gang-gang tersebut juga banyak terjadi aktivitas warga, seperti 
bercengkerama dengan tetangganya, melakukan beberapa permainan atau berolah raga ringan seperti bulutangkis, bahkan sampai ada yang berjualan.

Beberapa aktivitas di Kauman bersifat musiman, salah satunya adalah pasar tiban. Pasar ini hanya muncul ketika memasuki Ramadhan. Jajanan yang diperjual-belikan adalah jajanan untuk berbuka puasa. Adanya pasar tersebut menambah riuhnya aktivitas di Kampung Kauman. Ramainya pengunjung dari dalam dan luar kampung menambah padatnya jalan yang sudah sempit.

Kampung Kauman awalnya merupakan kampung untuk para abdi dalem Kraton Yogyakarta. Namun, semakin banyaknya keturunan dari abdi dalem maka semakin banyak pula orang yang sekarang tinggal di dalam kampung tersebut. Warga Kampung Kauman awalnya hanya bekerja sebagai abdi dalem saja, namun ternyata ada peluang di sektor ekonomi yang baru, yaitu kerajinan batik. Sampai saat ini kerajinan batik merupakan sumber penghasilan warga Kampung Kauman.

Pendidikan di Kampung Kauman bertumpu pada pesantren, namun ada juga yang belajar mengaji di langgarlanggar dan masjid. Selain itu, ada beberapa warga yang mampu dari segi ekonomi memilih untuk belajar ke luar negeri, kebanyakan dari mereka ke luar negeri dalam rangka memperdalam ilmu agama Islam.

Berbeda dengan kampung lain yang ada di Yogyakarta, Kampung Kauman sejak awal sudah merupakan kampung yang dihuni oleh masyarakat kota, karena sejak awal kampung tersebut merupakan tempat tinggal dari para abdi dalem dan keluarganya, yang merupakan penduduk kota. Hampir tidak ada warga pindahan dari desa yang tinggal di Kauman, berbeda dengan kampung lain yang warganya merupakan pindahan dari desa. Hal tersebut menyebabkan warga Kampung Kauman sudah sangat paham dengan Kota Yogyakarta, terutama terhadap Kraton Yogyakarta. Kampung Kauman tumbuh menjadi kampung yang sangat kental dengan kehidupan yang mengandung nilai-nilai Islami yang telah diajarkan oleh K.H. A. Dahlan.

Aktivitas yang terjadi di Kauman berkaitan dengan negosiasi ruang. Dalam hal ini negosiasi terjadi antara dua pihak dan menghasilkan ruang sosial sementara yang menguntungkan bagi keduanya atau salah satu pihak saja dan pihak lainnya tidak mengalami kerugian maupun keuntungan. Negosiasi ruang ini menarik karena mengakibatkan terciptanya ruang baru secara sementara. Ruang baru tersebut menimbulkan sequence yang berbeda dengan ruang yang sebelumnya.

\section{Metode Penelitian}

Penelitian dilaksanakan dengan pendekatan studi secara deskriptif kualitatif berdasarkan fenomena ruang yang ada di Kampung Kauman Yogyakarta. Metode pengamatan lapangan digunakan untuk memetakan kondisi ruang yang ada di Kampung Kauman Yogyakarta, beserta dengan aktivitas pelaku yang terjadi di dalamnya. Metode survei digunakan untuk mendapatkan data primer tentang kondisi Kampung Kauman yang terkini, kemudian dianalisis bersama dengan data sekunder atau literatur tentang kampung kota dan Kampung Kauman. Survei dilakukan di area Kampung Kauman pada bagian jalan kampung dan area Masjid Agung. Wawancara dilakukan dengan mengajukan pertanyaan-pertanyaan singkat mengenai terbentuknya ruang sosial kepada beberapa warga. 
Warga yang diwawancarai adalah pedagang sayur keliling yang membuat ruang sosial di tempat dia berjualan dan warga yang melakukan peluasan teritorial dengan menjemur pakaian (perluasan tersebut menggunakan ruas jalan kampung), juga beberapa anak dan pedagang yang menggunakan halaman masjid untuk beraktivitas.

\section{Pembahasan}

Kampung Kauman Yogyakarta berada di daerah sekitar kompleks Keraton Yogyakarta, tepatnya di sebelah barat Alun-alun Utara Yogyakarta. Kauman juga dekat dengan Rumah Sakit PKU Muhammadiyah. Rumah Sakit tersebut berada tepat di utara Kauman. Foto udara Kampung Kauman dapat dilihat pada gambar 1 berikut.

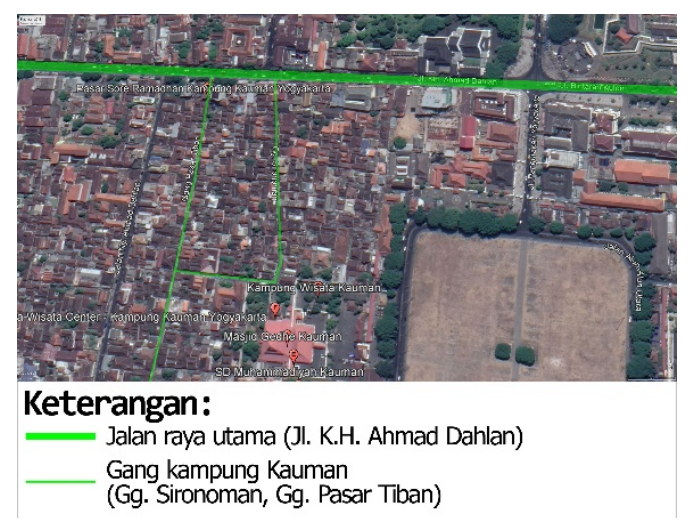

\section{Gambar 1. Foto udara Kampung Kauman Yogyakarta Sumber:}

https://goo.gl/maps/mbQq1a28bUx7sMsD6, diolah oleh Panglipur, diakses 28 Januari 2020

Saat ini Kauman masih menjadi pusat pendidikan agama Islam di Yogyakarta, khususnya ajaran Islam Muhammadiyah. Peninggalan ajaran dari K.H. A. Dahlan ini secara turun temurun dilestarikan oleh para penduduk di Kauman, yaitu para $a b d i$ dalem dan keluarganya. Langgar milik K.H. A. dahlan pun masih ada di kampung ini, hal ini secara tidak langsung menunjukkan bahwa ajaran beliau benar-benar lestari, namun untuk menuju langgar tersebut harus melalui gang-gang sempit dan kecil (gambar 2, 3, 4 dan 5).

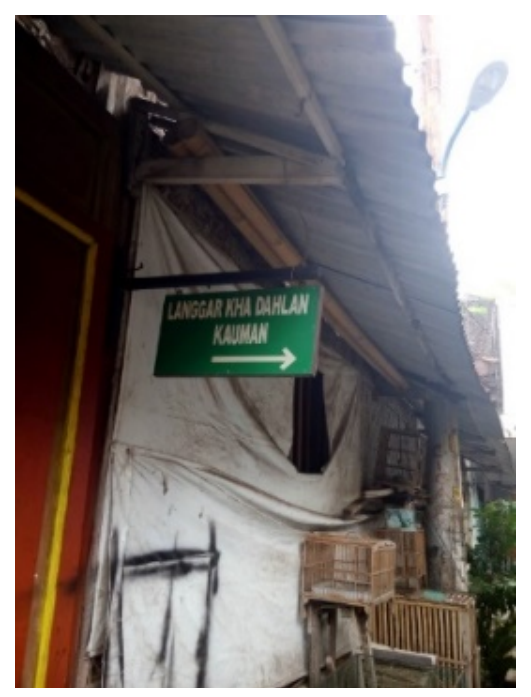

Gambar 2. Signage menuju Langgar K.H.

$$
\text { A. Dahlan }
$$

Sumber: Dokumentasi Panglipur, 2018

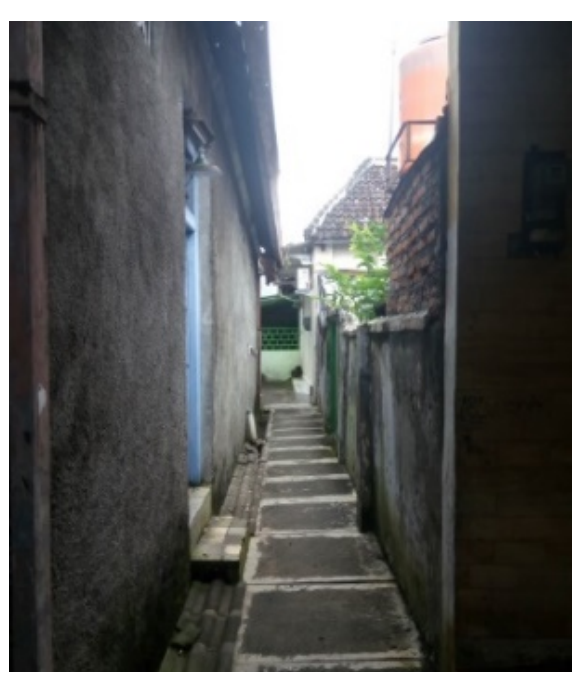

Gambar 3. Gang sempit menuju Langgar K.H. A. Dahlan

Sumber: Dokumentasi Panglipur, 2018 


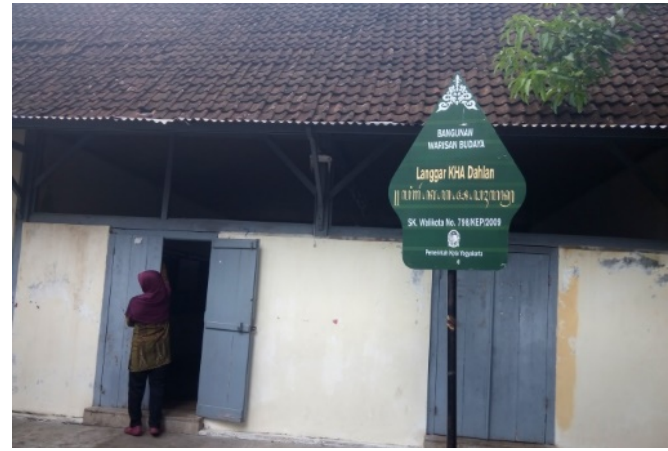

Gambar 4. Kompleks Langgar K.H. A. Dahlan

Sumber: Dokumentasi Panglipur, 2018

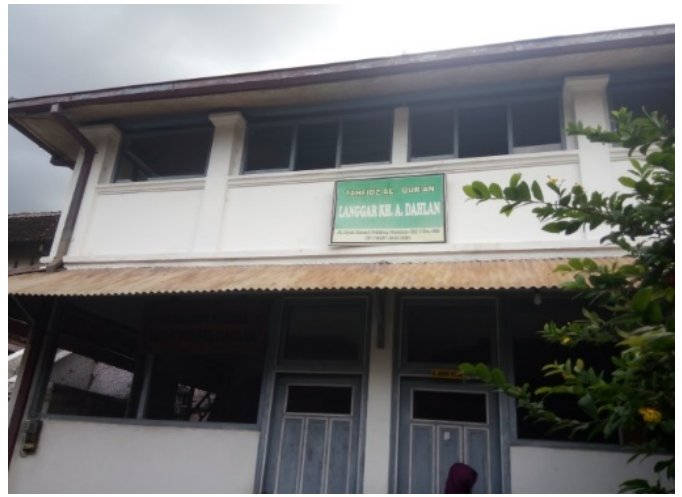

Gambar 5. Langgar K.H. A. Dahlan

Sumber: Dokumentasi Panglipur, 2018

Material jalan di Kampung Kauman Yogyakarta tidak menggunakan aspal, melainkan batako. Hal ini secara otomatis juga telah menyatakan bahwa tidak boleh berkendara dengan kecepatan tinggi, karena batako tidak menghasilkan gaya gesek sebesar aspal, sehingga jika ada pengendara sepeda yang mengerem tidak bisa langsung berhenti (gambar 6 dan 7). Hal ini dilakukan karena di area kampung tersebut banyak anak-anak yang beraktivitas sehingga larangan-larangan untuk tidak mengendarai sepeda dengan kecepatan tinggi dilakukan karena bisa mencelakai anak-anak tersebut. Selain itu, mengendara sepeda dengan kecepatan tinggi di gang-gang kecil seperti Kauman dapat membahayakan pengendara tersebut.

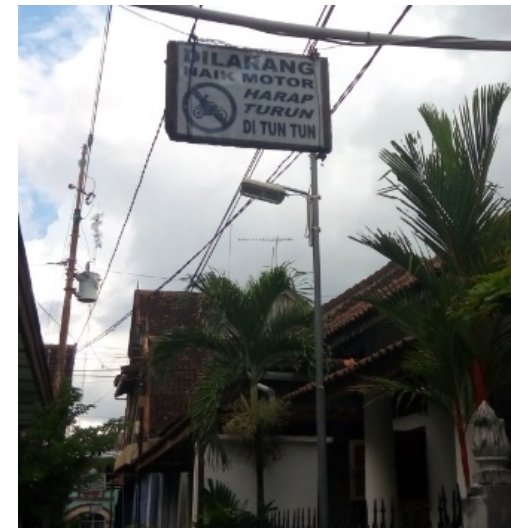

Gambar 6. Signage himbauan agar menuntun sepeda motor

Sumber: Dokumentasi Panglipur, 2018

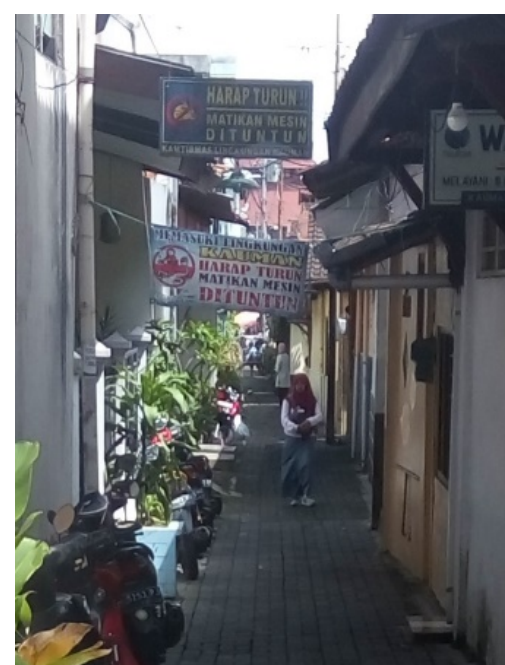

Gambar 7. Material jalan di kampung menggunakan batako

Sumber: Dokumentasi Panglipur, 2018

Ruang-ruang jalan di Kauman terbentuk oleh aktivitas warganya, hal ini seperti yang dikatakan oleh Laurens (2004:107-108) tentang perilaku sosial manusia yang berkaitan dengan lingkungan fisik yang ada, yaitu ruang personal, teritorialitas, kesesakan dan kepadatan, serta privasi. Beberapa ruang di Kauman yang terbentuk oleh aktivitas warganya dapat dilihat pada gambar 8 berikut ini. 


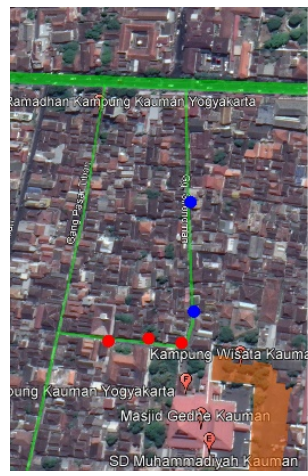

Keterangan:

Ruang sosial yang dibuat oleh pedagang sayur keliling.

Perluasan teritori personal warga dengan cara menjemur pakaian di ruas gang kampung.

Ruang sosial yang dibuat oleh anak-anak dan pedagang asongan digunakan untuk berlatih Pencak Silat, area bermain dan berdagang.

Gambar 8. Letak ruang-ruang sosial yang disebabkan aktivitas warga Kampung Kauman

Sumber:

https://goo.gl/maps/mbQq1a28bUx7sMsD6, diolah oleh Panglipur, diakses 28 Januari 2020

Salah satu contoh adalah seorang pedagang sayur di gang kampung yang berjualan di depan rumah-rumah warga dan berpindah-pindah (lihat pada titik berwarna biru di gambar 8). Ia menggunakan meja untuk membatasi ruang antara pembeli dan dirinya sebagai penjual. Meskipun hanya dalam beberapa jam saja (karena sekitar pukul 14.00 WIB sudah pindah tempat), ia berhasil memanfaatkan ruang yang ada untuk dirinya berjualan. Pedagang sayur tersebut sukses membuat ruang baru pada ruas jalan kampung.

Ia juga berhasil membuat demarkasi ruang personal yang membatasinya dengan pembeli yang berdatangan. Ruang personal yang dimaksud adalah sebuah batas tak kasat mata, yang secara otomatis tercipta untuk membatasi diri dengan orang lain, seperti yang dikemukakan oleh Laurens (2004:108) tentang ruang personal. Apabila ada pembeli yang ingin berinteraksi dengan ibu penjual sayur ini, maka ia harus mendekat, paling tidak dalam radius 1-2 meter dari si penjual. Dengan demikian, secara otomatis pembeli masuk kedalam jarak sosial (fase dekat) darinya. Karena jika terlalu jauh atau lebih dari 2 meter, maka akan menjadi tidak nyaman untuk mereka berinteraksi. Pedagang tersebut juga membuat teritorial secara sementara untuk berjualan. Dapat dilihat pada gambar 9 bahwa beliau menggunakan sepeda, payung dan meja untuk menandai teritorialnya sehingga wilayahnya terlihat secara fisik. Posisi pedagang tersebut dalam peta Kampung Kauman dapat dilihat di gambar 8 pada titik berwarna biru.

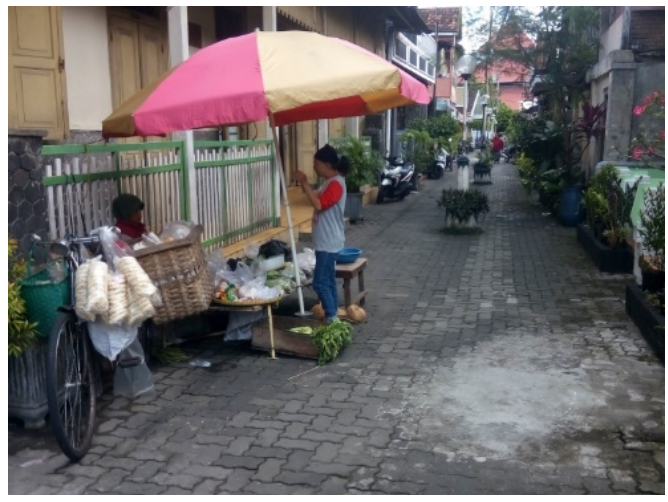

Gambar 9. Kegiatan berjualan di jalan kampung

Sumber: Dokumentasi Panglipur, 2018

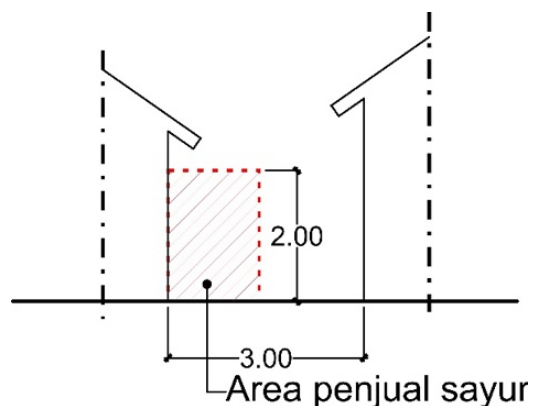

Gambar 10. Potongan area penjual sayur Sumber:Hasil analisis Panglipur, 2018

Secara tidak langsung pedagang tersebut sudah membuat ruang sosial baru berdasarkan negosiasi spasial dengan pemilik rumah yang bagian depannya akan ia tempati untuk berjualan.

Contoh lain adalah ketika sebagian ruas jalan digunakan oleh beberapa warga untuk menjemur pakaian dan tidak ada yang melarang atau marah (lihat pada titik merah di gambar 8). Kesepakatan antar pelaku aktivitas inilah yang 
membuat ruang di Kauman menjadi nyaman. Dalam hal ini beberapa warga yang menjemur pakaian di ruas jalan secara tidak langsung memperluas teritorialnya, yang tadinya hanya seluas teras rumahnya saja. Dengan meletakkan jemuran di ruas jalan, maka secara otomatis menyatakan bahwa ruas jalan tersebut masuk ke dalam teritorial mereka (lebih tepatnya perluasan teritorial). Perluasan teritorial ini tidak akan terjadi jika tidak ada jemuran di ruas jalan tersebut karena ruas jalan tersebut adalah milik umum.

Hal ini mirip dengan ilustrasi yang ditulis oleh Laurens (2004:124) tentang kursi di kantin. Saat ada yang sedang menduduki kursi di kantin dan ingin pergi ke toilet sebentar, maka ia akan meletakkan tas atau barang miliknya pada kursi tersebut, supaya menjadi tanda bahwa kursi itu sudah ia duduki dan tidak ada orang lain yang boleh mendudukinya. Secara otomatis, tindakan ini menyatakan bahwa kursi tersebut sudah menjadi miliknya dan tidak boleh ada yang mendudukinya meskipun ia tidak berada di kursi tersebut. Sebaliknya, jika ia tidak meletakkan tas pada kursi tersebut maka kursi tersebut menjadi hak semua orang. Hal ini serupa dengan ruas jalan yang digunakan untuk menjemur pakaian di Kampung Kauman. Untuk lebih jelasnya dapat dilihat pada gambar 11. Sedangkan posisi jemuranjemuran yang diletakkan di jalan dapat dilihat pada titik merah di gambar 8 .

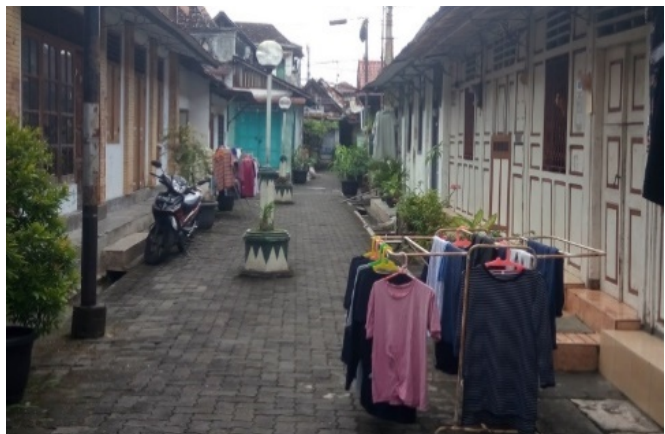

Gambar 11. Jalan kampung digunakan untuk menjemur pakaian

Sumber: Dokumentasi Panglipur, 2018

Kejadian ini sebenarnya menguntungkan setiap warga yang terlibat dalam perluasan teritorinya, warga yang menjemur pakaian di tepi gang juga akan menyebabkan warga lain melakukan hal yang sama, namun tidak mengganggu pengguna gang, karena pada umumnya pengguna gang adalah pejalan kaki.

Di Kauman juga terdapat beberapa peraturan kampung untuk belajar, salah satunya adalah jam belajar masyarakat seperti yang ada pada kampung lain, namun uniknya adalah di Kauman juga ada peraturan jam mengaji. Hal ini sangat penting untuk tetap memelihara iman Islam yang dimiliki oleh warga kampung tersebut. K.H. A. Dahlan telah berhasil mengajarkan hal-hal positif kepada warga Kauman dalam memelihara iman Islam.

Pandangan ruang-ruang sempit di Kauman tersibak menjadi luas ketika memasuki kompleks Masjid Agung Kauman (lihat pada bagian berwarna oranye di gambar 8). Di kompleks ini, tersedia ruang terbuka yang dimanfaatkan untuk latihan pencak silat dan menjadi lokasi bermain bagi anakanak warga Kampung Kauman. Aktivitas ini sesuai dengan apa yang sudah dikatakan Laurens (2004:107) bahwa perilaku sosial manusia dapat dilihat dari fenomena perilakulingkungan; kelompok-kelompok 
pemakai; dan tempat terjadinya aktivitas. Foto-foto aktivitas bermain anak-anak di kompleks Masjid Agung dapat dilihat pada gambar 12. Aktivitas berjualan para pedagang asongan (PKL) dapat dilihat pada gambar 13. Aktivitas latihan pencak silat yang dilakukan anak-anak Kampung Kauman dapat dilihat pada gambar 14.

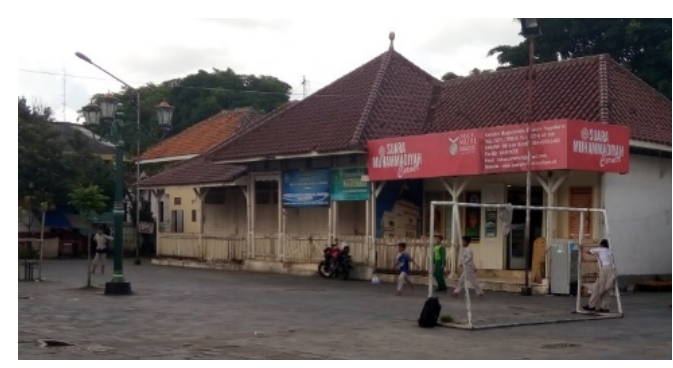

Gambar 12. Anak-anak bermain sepakbola di kompleks Masjid Agung

Sumber: Dokumentasi Panglipur, 2018

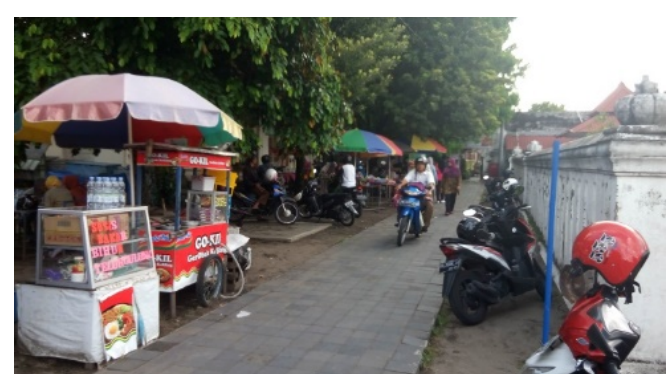

Gambar 13. PKL memanfaatkan peluang di kompleks Masjid Agung

Sumber: Dokumentasi Panglipur, 2018

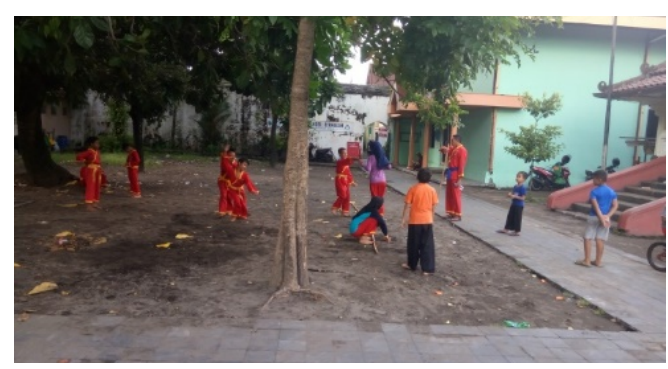

Gambar 14. Anak-anak berlatih pencak silat di kompleks Masjid Agung

Sumber: Dokumentasi Panglipur, 2018

Kegiatan latihan pencak silat diikuti oleh hampir semua anak di Kauman. Selain latihan pencak silat, ada juga anak-anak yang bermain sepak bola di halaman Masjid Agung tersebut.
Terjadinya kesepakatan antara warga dan pengurus masjid menyebabkan lokasi halaman Masjid Agung Kauman diperbolehkan untuk aktivitas latihan pencak silat. Aktivitas anak-anak tersebut menyebabkan para pedagang hadir untuk melayani anak-anak yang kelelahan, membutuhkan air minum dan atau makanan sehingga terjadi aktivitas jual-beli di halaman Masjid Agung Kauman.

\section{Kesimpulan}

Aktivitas manusia merupakan penyebab terjadinya ruang. Perilaku manusia dalam lingkungan sekitarnya merupakan hal yang menyebabkan terciptanya ruang. Kegiatan antar warga di Kauman juga salah satu penyebab terciptanya ruang sosial. Kesepakatankesepakatan yang tercipta dari negosiasi antar warga pun demikian. Meskipun memiliki ruang yang unik (sempit dan tidak boleh berkendara) namun itu bukan menjadi penghalang warga membuat ruang sosial baru akibat negosiasi spasial berdasarkan aktivitas mereka sehari-hari. Negosiasi tersebut menguntungkan salah satu atau kedua belah pihak.

Berdasarkan ketiga kasus yang telah diamati dan dianalisis, maka dari aktivitas pertama (kasus pedagang yang berjualan berpindah-pindah) terjadi negosiasi yang menguntungkan kedua belah pihak. Kasus kedua, menunjukkan bahwa aktivitas sesehari yang dilakukan berulang oleh warga (menjemur pakaian) akan menyebabkan terjadinya kesepakatan antar warga, tetapi juga tidak mengganggu pengguna gang Sedangkan pada kasus ketiga (anakanak beraktivitas di kompleks Masjid Agung), juga menyebabkan banyak pihak yang diuntungkan.

Dengan demikian, maka ruang dapat terjadi atau terbentuk dari negosiasi 
para pelakunya. Mereka dapat membuat ruang sosial berdasarkan kesepakatan yang terjadi seperti pada contoh kasus di Kampung Kauman.

\section{Daftar Pustaka}

Darban, A. A. (2000). Sejarah Kauman: Menguak identitas kampung Muhammadiyah. Yogyakarta: Penerbit Tarawang.

Laurens, M. J. (2004). Arsitektur dan perilaku manusia. Jakarta: PT Grasindo.

Sativa. (2012). Konsep teritori Kampung Kauman Yogyakarta. Inersia, Vol. VIII, No. 2, 110116. 